Dr SLOBODAN SELINIĆ, naučni saradnik Institut za noviju istoriju Srbije

\title{
POSETA PREDSEDNIKA JUGOSLAVIJE JOSIPA BROZA TITA SAP VOJVODINI, 18-21. april 1969.*
}

\begin{abstract}
APSTRAKT: U članku je opisan tok posete jugoslovenskog predsednika Josipa Broza Tita Socijalističkoj autonomnoj pokrajini Vojvodini 1969, dat je pregled osnovnih karakteristika privrednog razvitka ove srpske pokrajine i analizirani su osnovni stavovi izneti tokom posete u govorima Josipa Broza i njegovim razgovorima sa pokrajinskim i republičkim rukovodstvima.
\end{abstract}

Ključne reči: Josip Broz, SAP Vojvodina, Srbija, privreda, poljoprivreda

Predsednik Jugoslavije Josip Broz je tokom svoje vladavine imao nekoliko stotina poseta gradovima, republikama, pokrajinama, različitim manifestacijama i ustanovama širom Jugoslavije. Poseta severnoj pokrajini Srbije 1969. bila je jedna od značajnijih iz nekoliko razloga: Tito je tada posetio oblast u kojoj su privredni problemi bili nagomilani i ozbiljni, a do posete je došlo u periodu posle burne 1968, u godinama ustavnog preoblikovanja jugoslovenske države, u trenutku kada je bilo jasno da privredna reforma iz 1965. nije uspela i kada je nacionalno pitanje već bilo javno otvoreno. Poseta jugoslovenskog predsednika Vojvodini je trajala od 18. do 21. aprila 1969.

Program posete su početkom aprila predložila rukovodstva Vojvodine i Srbije. U program je bio uključen i jedan dan odmora u Karađorđevu „bez zvaničnih obaveza“, uz „eventualan lov na srndaće“. O organizaciji posete brinuo se šef protokola Predsednika Republike Vlado Šestan. ${ }^{1}$

* Rad je deo projekta Srbi i Srbija u jugoslovenskom i međunarodnom kontekstu: unutrašnji razvitak i položaj u evropskoj/svetskoj zajednici (47027), koji finansira Ministarstvo prosvete, nauke i tehnološkog razvoja Republike Srbije.

${ }^{1}$ Arhiv Jugoslavije (AJ), fond 837, KPR, II-1/162, Poseta SAP Vojvodini, Pripremni materijal. 


\section{Četvorodnevna poseta: gradovi, sela, fabrike, sastanci i mitinzi}

Tito je na put krenuo iz Karađorđeva. U njegovoj pratnji su bili predsednik Skupštine Vojvodine Ilija Rajačić, predsednik Pokrajinskog komiteta SK Mirko Čanadanović, predsednik Pokrajinskog izvršnog veća Stipan Marušić i predsednik Socijalističkog saveza Maćaš Kelemen. Prvi grad koji je posetio bio je Novi Sad. Na ulasku u novosadsku komunu, u selu Begeču, Tita su 18. aprila dočekali građani i slavoluk ukrašen cvećem i transparentom na kome je pisalo "Dobro nam došao dragi naš druže Tito“. Delegaciju su pozdravljali đaci sa zastavicama, a na kućama duž puta niz Begeč bili su stavljeni ćilimi sa Titovim portretima. Prvi razgovor Tito je imao u novosadskoj opštinskoj skupštini gde su njega i Jovanku Broz dočekali predstavnici Srbije (predsednici Skupštine Srbije Miloš Minić, CK SKS Marko Nikezić i Izvršnog veća Srbije Đurica Jojkić), kao i predsednik novosadske skupštine Dušan Ilijević, sekretar Opštinskog komiteta Dušan Popović i predstavnici SUBNOR-a, SSRN-a, sindikata i omladine. Titu i Jovanki su predati buketi crvenih karanfila. Ilijević je predsednika države upoznao sa posleratnim razvitkom Novog Sada, grada koji je krajem 60 -ih godina imao više zaposlenih u društvenom sektoru nego što je na kraju rata imao stanovnika (Novi Sad je 1945. imao 60.000, a 1969. oko 160.000 stanovnika, od kojih je 70.000 radilo u društvenom sektoru). Iz opštinske skupštine delegacija na čelu sa Titom se uputila u industrijsku zonu Novog Sada i posetila najveću fabriku Novkabel, koja je zapošljavala 1.600 radnika. Direktor Franjo Gosarić i predsednik radničkog saveta Pavle Barbarić proveli su goste kroz metalurški i kablovski pogon. Iz industrijskog dela Novog Sada Tita je put vodio u univerzitetski, pa je u rektoratu razgovarao sa delegacijom univerziteta na čelu sa rektorom Dragoljubom Dimkovićem i održao govor studentima. Sledila je poseta „najvećoj posleratnoj izložbi vojvođanskih likovnih stvaralaca" u Galeriji Matice srpske povodom 25 godina AVNOJ-a. Ovde je jugoslovenski predsednik razgledao više od 400 dela 65 slikara i vajara. Posetu Novom Sadu Tito je okončao na Iriškom vencu gde je položio venac na spomenik vojvođanskim partizanima. Vraćajući se iz Novog Sada u Karađorđevo kratko se zadržao u Bačkoj Palanci, gde su "gotovo svi stanovnici“ izašli na ulice da ga pozdrave. ${ }^{2}$

Drugog dana posete Vojvodini, 19. aprila 1969, Josip i Jovanka Broz su putujući kroz mesta po Bačkoj prešli više od 200 km. ${ }^{3}$ Tito je kroz neka

\footnotetext{
${ }^{2}$ Politika, 19. april 1969, 1, 2.

${ }^{3}$ Tog dana Tito je prošao kroz Bački Jarak, Temerin, Bačko Gradište, Bečej, Bačko Petrovo Selo, Mol, Adu, Sentu, Kanjižu, Martonoš, Horgoš, Bačke Vinograde, Hajdukovo, Palić, Suboticu, Malu Bosnu, Mišićevo, Bajmok, Aleksu Šantić, Srpski Miletić i Sombor. - Politika, 20. april 1969, 1.
} 
od ovih mesta samo prošao, a u nekima se zadržavao, ali i tada kratko. U Bečeju se obratio građanima kratkim govorom, odmorio u hotelu „Zadrugar“, a onda obišao „bački vulkan“, tj. erupciju gasa pored Bečeja, želeći da se uveri „u kolikoj meri ova erupcija predstavlja opasnost za stanovnike Bečeja“, pa su ga generalni direktor Naftagasa Andraš Kovač i šef stručnog štaba inž. Radmilo Marojević upoznali sa merama koje su preduzete da bi se ova stihija smirila. Uz jugoslovenske, na ovom objektu su radili i čehoslovački i mađarski stručnjaci, a Tito je pre odlaska napravio nekoliko snimaka. Zatim je u Adi razgledao pogone fabrike alatnih mašina i zupčanika Potisje, koja je proizvodila strugove i za američko, kanadsko i švedsko tržište. Tita je put dalje vodio kroz Sentu i Kanjižu, gde je održao kraće govore građanima, potom kroz Palić, sve do Subotice, gde mu je priređen svečani ručak u hotelu Patrija i gde ga je dočekao Karolj Bagi, predsednik opštinske skupštine. Drugi dan posete severnoj srpskoj pokrajini Tito je završio u Somboru i Odžacima. U Somboru je u opštinskoj skupštini razgovarao sa predstavnicima poljoprivrednih organizacija i seljaka somborske i apatinske komune. ${ }^{4}$

Organizovani dočeci, slavoluci, parole, buketi cveća, pokloni, deca, radnici, seljaci, borci iz rata koji su svi zajedno morali da budu deo dekora dočeka predsednika države - sve je to bila stalna slika sa Titovih putovanja po zemlji, ali je poseta Vojvodini bila prilika da se ljubav i odanost vođi još jače istaknu, jer je Tito sa suprugom i saradnicima $u$ jednom danu posetio veliki broj mesta. Opisujući drugi dan posete Vojvodini, novinar Politike Siniša Nikolić je sutradan javio: „Duž puteva na desetine hiljada oduševljenih Bačvana, razdraganih đaka, seljaka i radnika, pozdravile su dragog gosta poklicima i slavolucima dobrodošlice, a kroz sva naseljena mesta putevi su bili posuti svežim poljskim cvećem... Predsednik je na traženje razdraganog naroda morao da zastaje i tamo gde to prema protokolu nije bilo predviđeno, da govori, da sluša i pripremljene i spontane govore, prima poklone“. Tokom puta od Subotice do Sombora, „najoriginalniji doček“ svom predsedniku priredili su meštani Tavankuta, gde su „mladići i devojke, članovi kulturno-umetničkog društva Matija Gubec, nasred puta odigrali temperamentno Bunjevačko kolo". ${ }^{5}$

Trećeg dana posete Vojvodini, 20. aprila, Tito se umesto sa narodom susreo sa rukovodiocima. Tog dana je $\mathrm{u}$ Karađorđevu primio delegaciju SAP Vojvodine. Četvorodnevna poseta pokrajini završena je 21. aprila. Tito je iz Karađorđeva, preko Kaća, Šajkaša, Vilova, Iloka, Titela, Perleza i Čente doputovao u Pančevo. Okupljenom narodu je održao govor na gradskom trgu, a onda posetio Rafineriju nafte i Hemijsku industriju Pančevo. Na

\footnotetext{
${ }^{4}$ Politika, 20. april 1969, 1, 2.

${ }^{5}$ Isto.
} 
ulasku u rafineriju Tita su dočekali generalni direktor Naftagasa Andraš Kovač, direktor rafinerije Mita Boškov i predsednik SIV-a Mika Špiljak, a kroz pogone Hemijske industrije proveli su ga generalni direktor Imre Teke i tehnički direktor Dimitrije Lazović. ${ }^{6}$

Tokom posete Vojvodini Tito je dobio veliki broj poklona. Prema spisku koji je sastavio pešadijski major Miloš Milisav, njih je bilo 22: najviše umetničkih slika (8), a među darovima su bili i albumi sa fotografijama, muške i ženske kožne torbe, pribor za radni sto, ženski kišobran, ženska narodna torba iz okoline Pančeva, flaša za sifon vodu. ${ }^{7}$

\section{Tito i narod: demagoške poruke i fraze}

U odnosu na mnoge druge Titove javne nastupe $\mathrm{u}$ zemlji, poseta Vojvodini se izdvajala po tome što on, iako je posetio veliki broj mesta i održao više javnih govora, nije održao nijedan značajan govor koji bi istorija pamtila. Njegovi nastupi pred građanima bili su upadljivo kratki i sadržajno prazni, sastavljeni uglavnom od nekoliko demagoških floskula koje je uporno ponavljao iz mesta u mesto. Gotovo da nije dotakao nijedno goruće pitanje, osim uopštenih zaključaka o slabijem industrijskom razvitku Vojvodine. Iako su razlozi za posetu Vojvodini bili ozbiljni, o „velikim“ temama se govorilo samo na zatvorenim sastancima sa privrednim i političkim rukovodiocima.

I javno, u obraćanju građanima, i na zatvorenim sastancima, u razgovorima sa privrednim, partijskim i političkim rukovodiocima, Tito je tvrdio da su na njega tokom obilaska Vojvodine najveći utisak ostavili narod i zasejana vojvođanska polja („sve je izorano, sve je posijano“). To je deo njegovog nastupa u kome su demagoške fraze dobile pun izraz. Narod je hvalio jer je "gledao u budućnost" i bio zadovoljan onim što je postignuto. Iako je priznavao da su rukovodioci u prošlosti pravili greške, Tito je tvrdio da narod nije na njih bacao „krivnju“, već je objektivno gledao na situaciju u zemlji. $^{8}$

Višenacionalni karakter Vojvodine bio je povod da Tito u obraćanjima građanima potencira potrebu čuvanja bratstva i jedinstva. To je i inače bila jedna od njegovih najčešćih poruka Jugoslovenima. U multietničkoj

\footnotetext{
${ }^{6}$ Isto.

${ }^{7}$ AJ, 837, KPR, II-1/162, Poseta SAP Vojvodini, Pripremni materijal.

${ }^{8}$ AJ, 837, KPR, II-1/162, Poseta SAP Vojvodini, Odgovor predsednika Tita na zdravicu na ručku, Subotica, 19. april 1969; Razgovor sa rukovodstvom Vojvodine, 20. april 1969; Govor predsednika Tita, Titel, 21. april 1969; Govor predsednika Tita, Pančevo, 21.
} april 1969. 
Vojvodini te reči su dobijale na značaju. ${ }^{9}$ Ova tema je bila tim aktuelnija, jer je krajem 60-ih godina u Jugoslaviji već bilo otvoreno nacionalno pitanje i počeo je proces prekomponovanja države. U govorima u Senti, Kanjiži i Bečeju Tito je isticao značaj bratstva i jedinstva „koje se kovalo u ratu“, tvrdio da je Vojvodina, u kojoj su živele mnoge nacionalnosti, najbolji primer šta je značilo bratstvo i jedinstvo, upozoravao da ne postoje posebni interesi, već „svi zajednički imate jedan interes, to jest da gradite srećniju budućnost našim narodima i sebi, to jest da stvarate socijalističku Jugoslaviju“. ${ }^{10}$

Jugoslovenski predsednik je satima na zatvorenim sastancima razgovarao sa pokrajinskim rukovodstvom o ozbiljnim privrednim problemima pokrajine, ali se tih pitanja u javnim nastupima doticao samo ovlaš i uopšteno i to uglavnom samo utoliko što nije krio nezadovoljstvo stepenom razvitka industrije u Vojvodini. U Adi je obišao fabriku alatnih mašina Potisje i upozorio da razvoj industrije u Vojvodini „nije otišao tako daleko“ kao u drugim delovima Jugoslavije. U Senti je iskazao želju da industrija Vojvodine bude jača nego što je bila kako bi se sirovine na licu mesta prerađivale $\mathrm{u}$ finalne proizvode, a u Titelu je priznao da Vojvodina nije napredovala koliko je zaslužila i obećavao da će u vrhu partije i države nastojati da se stanje popravi. ${ }^{11}$

Poseta Tita Vojvodini je organizovana posle 9. partijskog kongresa, ${ }^{12}$ pa su u Titovim nastupima još uvek bile sveže ideje o posebnoj ulozi i najvećoj odgovornosti komunista u jugoslovenskom društvu. Suprotno stvarnosti u kojoj je moral komunista već bio izbledeo i komunistički funkcioneri nizom privilegija i mahinacija sve više odvajali sebe od običnog sveta, Tito i njegovi saradnici su javno govorili o potrebi da funkcioneri stupe u dodir sa običnim svetom, upoznaju probleme svojih sugrađana, da im služe za primer i uzor. Tokom posete Vojvodini Tito je ponavljao da komunisti ne smeju da razočaraju, već moraju da daju primer kao što su ga davali u ratu, „primjer koji je koštao krvi mnoge naše članove partije, koji je koštao krvi mnogih naših rodoljubivih ljudi, sinova, kćeri, očeva itd.". Tražio je od

${ }^{9}$ Prema popisu iz 1961, u Vojvodini su Srbi činili 56\%, Mađari 24\%, Hrvati 7\%, Slovaci 4,2\%, Rumuni 3,1\%, Crnogorci 1,9\%, Rusini 1,3\% stanovnika. Gotovo trećina brakova bili su mešoviti (oko 30\%). - AJ, 837, KPR, II-1/162, Poseta SAP Vojvodini, Informativni materijal, Osnovne karakteristike privrednog i društveno-političkog razvoja.

${ }^{10}$ AJ, 837, KPR, II-1/162, Poseta SAP Vojvodini, Govor predsednika Tita u Senti; Govor predsednika Tita građanima Bečeja; Reč predsednika Tita u Kanjiži.

${ }^{11}$ AJ, 837, KPR, II-1/162, Poseta SAP Vojvodini, Govor predsednika Tita u Senti; Reč predsednika Tita građanima Ade; Govor predsednika Tita, Titel, 21. april 1969.

${ }^{12}$ Deveti kongres SKJ je održan marta 1969. U kongresnim rezolucijama se govori o razvitku samoupravljanja, ulozi SKJ, međunarodnoj situaciji itd. Na njemu je statutarno uveden paritet u sastavljanju partijskog rukovodstva Jugoslavije. Princip demokratskog centralizma je praktično napušten i partija od 1969. podleže federalizaciji. - AJ, 507/I, SKJ, I/IX-k. 1/1-15; B. Petranović, Istorija Jugoslavije 1918-1988, III, Beograd 1988, 391, 392. 
članova SKJ da zadrže revolucionarni duh: „25 godina Komunistička partija se borila za ovo što danas imamo... mi sada ostvarujemo ono zašto su se borili najbolji sinovi naše zemlje. Budimo dosledni sebi i produžimo dalje tim putem i ja mislim da ništa ne može biti vrednije, ništa ne može biti veće zadovoljstvo nego da si izvršio svoju dužnost pred svojim narodom. Svaki komunista neka stane na svoje mjesto gdje se nalazi, neka radi sve što najviše može. Rukovodioci treba da idu među narod dolje, da vide taj narod. Jer ja vam kažem, kad ja dođem u narod, meni to daje nekako nove snage i novi polet, ja se onda osjećam kao da sam počeo, kao da treba još više da dam od sebe“. ${ }^{13}$ U Titelu je precizirao šta očekuje od rukovodilaca: „da rukovodioci idu van među narod da vide šta bi trebalo da se učini, šta bi trebalo ukloniti što ne valja, šta bi trebalo poboljšati. Jednom riječju, da se upoznamo sa svim problemima koji stoje pred nama. "14 Ovakav zahtev je pravdao stavom da je „drugo dobiti papir pa čitati, a drugo je ići lično i lično se ubjediti, lično vidjeti u čemu je suština, vidjeti ljude, proizvođače itd. “15 Da se greške iz prošlosti neće ponavljati i da će obećanja sa 9. kongresa biti ispunjena, Tito je posebno naglašavao novosadskim studentima. Njegovo upozorenje da nikada više ne treba da se ponovi 1968, bilo je praćeno priznanjem da je zanemareno učešće omladine $u$ društvenom životu. ${ }^{16}$

U priču o potrebi rukovodilaca da idu u narod uklapalo se Titovo demagoško izvinjavanje građanima ovih mesta što ih nije ranije posetio, pravdajući se velikom zauzetošću. To je bio deo Titovog javnog nastupa u kome je najviše pokušavao da se približi običnim ljudima i pokaže da je jedan od njih, njihov „susjed“. U Bačkoj Palanci je rekao: „Ja sam vaš susjed ovdje i mislim da je bilo red da sam i prije došao u vašu sredinu. No ja sam mislio da je dovoljno da prođem pa da me vidite ovdje. A ja se nadam da će biti vrijeme kad ću moći sjesti s vama, sa vašim rukovodiocima, u vašoj sredini pa da malo porazgovaramo o problemima. Iako sam blizu tu često kod vas, ipak ne poznajem vaše probleme koji postoje i koje vi imate. Što se tiče naših odnosa susedskih ja mislim da problema nema i da ćemo se mi lako sporazumjeti ako ima nešto između nas."17 Građanima Sente se izvinjavao

${ }^{13}$ AJ, 837, KPR, II-1/162, Poseta SAP Vojvodini, Odgovor predsednika Tita na zdravicu na ručku, Subotica, 19. april 1969.

${ }^{14}$ AJ, 837, KPR, II-1/162, Poseta SAP Vojvodini, Govor predsednika Tita, Titel, 21. april 1969 .

${ }^{15}$ AJ, 837, KPR, II-1/162, Poseta SAP Vojvodini, Govor predsednika Tita, Pančevo, 21. april 1969.

${ }^{16}$ AJ, 837, KPR, II-1/162, Poseta SAP Vojvodini, Reč predsednika Tita studentima, Novi Sad, 18. april 1969; Politika, 19. april 1969, 2. Bačke Palanke.

${ }^{17}$ AJ, 837, KPR, II-1/162, Poseta SAP Vojvodini, Reč predsednika Tita građanima 
što prvi put posećuje ovo mesto iako je njegov počasni građanin. ${ }^{18} \mathrm{U}$ Kanjiži je priznao građanima da kroz njihov kraj prolazi kao „meteor": „Ja bih volio da ne bude tako, nego da dođem u svako mjesto da budem duže, da čujem vaše probleme, da čujem vaše teškoće i da vidim vašu radost zbog onoga što ste danas već postigli. No ja tu ne mogu ništa jer sam na takvom položaju da mogu veoma nakratko da zavirim po raznim krajevima naše zemlje. Budite uvereni da ovaj put lično meni ogromno doprinosi što se ja time osvežavam, vidim naše ljude da su radosnog života i to mi daje poleta i podstreka da izdržim na tom mjestu na kojem jesam, da radim koliko najviše mogu na dobro našeg naroda a tako isto misle i moji drugovi saradnici“" ${ }^{19}$

\section{Tito i rukovodioci: priča o privrednoj krizi}

Razgovori Josipa Broza i pokrajinskih i republičkih funkcionera daju drugačiju sliku od one koju pružaju Titovi govori narodu na mitinzima. Materijali koje je Josip Broz dobio pred posetu Vojvodini, kao i brojni podaci koje je čuo na sastancima sa vodećim političarima i privrednicima pokrajine, mogli su da ga uvere da je privreda u pokrajini bila u ozbiljnim problemima i da privredna reforma nije popravila stanje. Situacija u ekonomiji je bila ključna tema njegovih razgovora sa pokrajinskim predstavnicima. Šta nam o tom pitanju govore dokumenta o Titovoj poseti Vojvodini?

Vojvodina je po svojim karakteristikama i potencijalu trebalo da bude ekonomska lokomotiva zemlje. Velike i plodne poljoprivredne površine i brojne industrijske grane trebalo je da budu pretpostavka za snažan ekonomski razvitak ovog kraja Srbije. U stvarnosti, međutim, privreda Vojvodine je bila suočena sa brojnim problemima, pa je u nekim segmentima zaostajala za jugoslovenskim i srpskim nivoom. Deo tih problema je poticao od nedovoljnih ulaganja u industriju, što je Josip Broz, između ostalog, pravdao strahom od napada sa Istoka u godinama sukoba sa Informbiroom, a dugi deo je bio vezan za dugogodišnje zapostavljanje poljoprivrede $u$ posleratnoj privrednoj politici Jugoslavije.

Privredni potencijal Vojvodine je bio veliki. U pokrajini je bilo 1.580 ha plodnih oranica, to jest petina ukupnih oranica Jugoslavije. Železnička mreža se prostirala na $1.963 \mathrm{~km}$, bile su zastupljene gotovo sve industrijske grane. Vojvodina je imala oko $1.000 \mathrm{~km}$ plovnih puteva sa velikim bogatstvom vode. Značaj ovog dela Srbije za jugoslovensku ekonomiju je bio veliki. U 1967. godini u Vojvodini se proizvodilo $27 \%$ jugoslovenske proizvodnje pšenice, $40 \%$ kukuruza, $54 \%$ šećerne repe, $77,6 \%$ suncokreta, $23 \%$ mašina za obradu metala i drveta, $26 \%$ rotacionih mašina, 50\% šećera, 37\%

${ }^{18}$ AJ, 837, KPR, II-1/162, Poseta SAP Vojvodini, Govor predsednika Tita u Senti.

${ }^{19}$ AJ, 837, KPR, II-1/162, Poseta SAP Vojvodini, Reč predsednika Tita u Kanjiži. 
ulja, 29\% nafte, 47\% plina, 40\% mesnih konzervi. Privreda i društvo pokrajine su prolazili kroz iste promene kao i cela država. Nacionalni dohodak privrede bio je 1964. tri puta veći nego 1947. (pet puta u industriji i dva puta u poljoprivredi). Društveni sektor privrede u 1965. godini učestvovao je u nacionalnom dohotku sa $71 \%$. Učešće industrije je povećano sa $18,3 \%$ tokom 1947. na $28,3 \%$ u 1963, a učešće poljoprivrede je smanjeno sa $62,2 \%$ na 46\%. Učešće poljoprivrednog stanovništva je smanjeno sa $66,2 \%$ u 1948. na $49,8 \%$ tokom 1965 . U društvenom sektoru broj zaposlenih od 1955. do 1965. povećan je za 200.000, zapošljavanje u nepoljoprivrednim delatnostima je apsorbovalo priraštaj aktivnog stanovništva, prelivanje radne snage iz poljoprivrednih u nepoljoprivredne delatnosti i jedan deo imigracija iz drugih krajeva zemlje. ${ }^{20}$

Velika važnost Vojvodine za jugoslovensku privredu nije značila i da su ekonomske prilike u severnom delu Srbije bile zadovoljavajuće. Po mnogim parametrima Vojvodina je zaostajala za jugoslovenskim nivoom. Zbog slabijeg tempa razvitka u prvih desetak godina posle rata, nerešenog pitanja zastarelih industrijskih kapaciteta, zapostavljanja poljoprivrede i useljavanja velikog broja stanovnika tempo razvitka Vojvodine je do 1964. bio sporiji nego u celoj zemlji. Investicije po glavi stanovnika u periodu 19471962. bile su niže u Vojvodini za 12\% u odnosu na Jugoslaviju, a 19471956. iznosile su samo 50\% investicija po stanovniku Jugoslavije.

Industrija se u pokrajini sporije razvijala nego u državi. Rast nacionalnog dohotka u Vojvodini je bio ispod jugoslovenskog nivoa: od 1947. do 1964. prosečna stopa rasta je iznosila 7,1\% u Jugoslaviji i 6,3\% u Vojvodini. Veća ulaganja su nastupila tek od druge polovine pedesetih godina, pa je u periodu 1957-1963. uloženo 76\% svih posleratnih investicija u pokrajinu zahvaljujući sistemu kreditiranja. Uzimanje kredita, međutim, opteretilo je privredu Vojvodine, pa su prema završnim računima iz 1964. sredstva čistog prihoda (koja posle isplaćenih plata ostaju privrednim organizacijama) bila opterećena anuitetima sa čak $84 \%$, a poljoprivredne organizacije nisu mogle iz tih sredstava ni da vrše otplatu anuiteta, jer su oni za $21 \%$ premašivali njihova sredstva.

Oko 410.000 doseljenika koliko se uselilo u pokrajinu do 1961. dodatno je pojačavalo pritisak na privredu ( $u$ istom periodu iz pokrajine se iselilo 135.000 ljudi). Radna snaga koja se useljavala uglavnom je bila nekvalifikovana. Školska sprema onih koji su se iseljavali bila je bolja od spreme onih koji su se useljavali: sa višom i visokom spremom se iselilo oko 9.000, a uselilo 5.000; sa srednjom spremom se iselilo 17.000, a uselilo

${ }^{20}$ AJ, 837, KPR, II-1/162, Poseta SAP Vojvodini, Informativni materijal, Neke karakteristike... 
13.000 ljudi; suprotno od toga, veći broj nekvalifikovanih i polukvalifikovanih radnika se uselio nego iselio. ${ }^{21}$

Posebno je upadljivo bilo zaostajanje poljoprivrede, koja je imala veliki značaj za privredu Vojvodine (poljoprivreda je u nacionalnom dohotku Vojvodine učestvovala sa 50\%, a u Jugoslaviji sa 28\%, učešće poljoprivrednih proizvoda u ukupnom izvozu u Vojvodini bilo je 43,6\%, a u Jugoslaviji $17 \%){ }^{22}$ Poljoprivreda je posle rata na nivou cele zemlje bila u nepovoljnom položaju u godinama kampanjske industrijalizacije zemlje, pogođena nizom mera novih vlasti koje su imale veoma loše posledice na ovu privrednu granu (otkup, kolektivizacija). Od kraja rata do 1957. poljoprivredna proizvodnja je bila ispod predratnog proseka 1930-1939, osim 1953. Poljoprivreda se intenzivnije razvijala tek sa povećanjem ulaganja posle 1956, pa je od 1957. do 1959. uloženo više nego za prethodnih deset godina. Broj traktora je sa 5.000 u 1956. povećan na 13.500 u 1965, a potrošnja veštačkih đubriva sa $192 \mathrm{~kg}$ 1957. na $415 \mathrm{~kg} \mathrm{u}$ 1965. (društvena gazdinstva sa 625 na 901, a privatna sa 67 na $190 \mathrm{~kg}$ ). U prvoj polovini sedme decenije, međutim, investicije u poljoprivredu su ponovo stagnirale. ${ }^{23}$

Očekivalo se da ovakvo stanje privrede, pre svega poljoprivrede, $\mathrm{u}$ Vojvodini bude popravljeno privrednom reformom iz 1965, ali se to nije desilo, bar ne dugoročno. U 1965. i 1966. dinamika rasta privrede Vojvodine bila je iznad ili na nivou Jugoslavije i Srbije, ali je od 1967. počela da ponovo osetnije zaostaje. U Vojvodini je društveni proizvod privrede $\mathrm{u}$ 1968. bio niži za $0,5 \%$ u odnosu na 1967 , dok je u Srbiji bio za 2,3\%, a u Jugoslaviji za 4\% viši. U 1964. nacionalni dohodak po stanovniku bio je za 13,4\% iznad jugoslovenskog proseka, 1965. i 1966. 20\% iznad jugoslovenskog proseka, ali se od 1967. situacija pogoršava i 1967. bio je $16,6 \%$, a 1968. samo 10\% iznad jugoslovenskog proseka. To znači da je 1968. stanje u privredi Vojvodini bilo lošije nego pre reforme. S. Marušić je obavestio Tita da je posebno zabrinjavala činjenica da su vodeće industrijske grane (metalna, prehrambena i tekstilna, koje su činile $60 \%$ industrije), beležile najnepovoljnija kretanja. Izvoz sa područja Vojvodine je 1968. bio za 27\% niži u odnosu na 1967. (u poljoprivredi je smanjenje iznosilo 35\%). Obaveze po osnovu uzetih kredita gušile su privredu pokrajine: 1967. i 1968. obaveze po anuitetima bile su veće od raspoloživih fondova pokrajinske privrede. Isto je bilo u celoj Srbiji: svi anuiteti koje je 1967. trebalo da plati industrija premašivali su za 40 milijardi dinara sve fondove industrije. Zaposle-

${ }^{21}$ AJ, 837, KPR, II-1/162, Poseta SAP Vojvodini, Razgovor predsednika Tita sa delegacijom Vojvodine; Informativni materijal, Neke karakteristike...

${ }^{22}$ AJ, 837, KPR, II-1/162, Poseta SAP Vojvodini, Razgovor predsednika Tita sa delegacijom Vojvodine. karakteristike...

${ }^{23}$ AJ, 837, KPR, II-1/162, Poseta SAP Vojvodini, Informativni materijal, Neke 
nost $\mathrm{u}$ društvenom sektoru na teritoriji Vojvodine od 1965. bila je u stalnom opadanju: 416.200 zaposlenih u 1965, a 375.600 u 1968. Zbog toga je rastao broj nezaposlenih mladih stručnjaka. I po ovom pitanju je situacija u Vojvodini bila slabija nego u Jugoslaviji i Srbiji. U ovom periodu zaposlenost u Vojvodini opadala je za 2,3\% godišnje, u Jugoslaviji 0,4\%, a u Srbiji 0,1\%. Porast životnog standarda u Vojvodini je 1966/67. bio znatno usporeniji u odnosu na ostatak zemlje, prosečni lični dohoci u periodu januar-novembar 1968. bili su u Vojvodini 789, Srbiji 816, a SFRJ 853 dinara. U Vojvodini su posle 1965. dramatično usporene i investicije. Od 1965. do 1967. prosečna godišnja stopa rasta investicija u Vojvodini bila je samo $0,3 \%$, a u celoj zemlji 5,8\%. Od 1965. do 1968. investicije po stanovniku u Vojvodini bile su niže za $10 \%$ od jugoslovenskog proseka, a $7 \%$ od srpskog. Uzrok za ovakvo stanje ležao je pre svega u privredi Vojvodine u kojoj su najviše bile zastupljene poljoprivreda i niskoakumulativne grane industrije. Privredu je bilo teško modernizovati, jer su dominirala mala i srednja preduzeća (od 306 radnih organizacija 1969. samo 29 je zapošljavalo više od 1.000 radnika). Poput jugoslovenske privrede i privreda severne srpske pokrajine nije mogla da cenama svojih proizvoda konkuriše svetskom tržištu. Slaba produktivnost i višak zaposlenih činili su cene jugoslovenskih proizvoda previsokim. ${ }^{24}$

I položaj poljoprivrede posle reforme popravljen je samo nakratko. ${ }^{25}$ Sredstva kojima su poljoprivredne organizacije raspolagale bila su 1968. manje od četvrtine sredstava iz 1965. Pokrajinske vlasti je veoma brinuo proces „postepenog diferenciranja i osiromašenja, odnosno pogoršanja položaja jednog broja individualnih proizvođača" i to pre svega onih sa manje od 5 hektara. Na selu i u poljoprivrednim organizacijama postojao je višak radne snage, ali industrija nije bila u stanju da ga prihvati. Predsednik Privredne komore Vojvodine Đorđe Gvozdenović izneo je na sastanku sa Titom procenu da je robu koju je proizvodilo $58 \%$ stanovnika Vojvodine moglo da proizvede i njih $25 \%$. Taj višak radne snage, po njegovoj oceni, opterećivao je cenu koštanja: „Jugoslavija je u proizvodnji mesa osma u svetu. Što se tiče kvaliteta mesa malo nam ima ravne, recimo kod goveđeg na

${ }^{24}$ AJ, 837, KPR, II-1/162, Poseta SAP Vojvodini, Informativni materijal, Prilog za izradu materijala...

${ }^{25}$ U Jugoslaviji je posle reforme popravljen položaj poljoprivrede, pa je 1966. proizvodnja porasla $17 \%$, izvoz $12 \%$, društveni proizvod $7 \%$, produktivnost $20 \%$ itd. Krajem 1967. i tokom 1968, međutim, položaj poljoprivrede se pogoršava u celoj zemlji, u 1968. poljoprivredna proizvodnja opada za $4 \%$, a izvoz za čak $20 \%$. Razlozi su bili sledeći: opadanje cena poljoprivrednih proizvoda, teškoće oko izvoza zbog povećanja poljoprivredne proizvodnje u zapadnoevropskim zemljama koje su raznim merama štitile svoju proizvodnju, usporen rast kupovne moći stanovništva itd. - AJ, 837, KPR, II-1/162, Poseta SAP Vojvodini, Informativni materijal, Podsetnik o poljoprivredi. 
londonskom tržištu, koje je ujedno i svetsko tržište; kod konzervi je isto tako, u proizvodnji kukuruza takođe. Međutim, sa ovakvim cenama mi ne možemo da idemo tamo... Upoređenja koja bi pravili između naših krupnih gazdinstava i nekih napolju, pokazuju da smo mi njima ravni, ali čim dođemo kod cene koštanja, odmah ovi troškovi koji su rezultat viška radne snage daju drukčije rezultate. ${ }^{\prime 26}$

Tito je bio dobro upoznat sa problemima poljoprivrede severnog dela Srbije i cele zemlje. Pre polaska na put dobio je detaljne materijale o ovoj temi, a tokom posete je na sastancima sa pokrajinskim rukovodstvom i predstavnicima poljoprivrednih organizacija i seljaka dobio dodatne informacije. Problemi u kojima se nalazila ova privredna grana ipak nisu bili za uši običnih ljudi, već je o njima govoreno na zatvorenim sastancima Tita i privrednih i državnih rukovodilaca. Suočen sa obiljem negativnih pokazatelja o stanju u poljoprivredi, Tito je na sastanku sa predstavnicima radnih organizacija u poljoprivredi i individualnim proizvođačima u Somboru tražio krivce za takvo stanje i našao ih na svim stranama: kod proizvođača, prerađivačke industrije i "kod nas gore u državnoj upravi“. Konstatovao je da nije bilo planiranja proizvodnje i ugovaranja između prerađivačke industrije i proizvođača i tražio da se zaštite proizvođači kako bi bili sigurni da će prodati ono što proizvedu. Spoljnu trgovinu je kritikovao zato što nije "razrađivala tržište“, a izvoz, jer se radilo po principu „torbarenja“, umesto da se sa velikim količinama robe izlazi na konvertibilno tržište. Nije zaboravio da pomene ni negativne posledice politike zapadnih zemalja koje su zaštitile svoju poljoprivredu, čime je posebno Italija nanela štetu Jugoslaviji. ${ }^{27}$

Sledeća važna tema razgovora Tita i pokrajinskog i republičkog vrha bila je naftna industrija. Poseta naftnoj industriji je organizovana u trenutku kada je Naftagas imao 18 pogona na teritoriji Srbije, Crne Gore i Makedonije, dva pogona za preradu nafte (rafinerija u Pančevu i destilacija $u$ Novom Sadu), zapošljavao 4.000 ljudi, od toga 464 inženjera i drugih visokokvalifikovanih stručnjaka i 1.500 tehničara, pri čemu su nekvalifikovani radnici činili samo 9\% zaposlenih. Preduzeće je raspolagalo sa oko 1.500 stanova, društvenim restoranima, letovalištima u Budvi i Bečićima, u jugoslovenskoj proizvodnji nafte je učestvovalo sa $30 \%$, a gasa sa $50 \%$. To je, međutim, bila jedna strana medalje. Naftna industrija je, s druge strane, bila suočena sa nizom problema, od kojih su najveći bili stagniranje novih istraživanja nafte, konkurencija i nerentabilna proizvodnja, jer su proizvodni kapaciteti bili veći od potreba tržišta, kao i sporost u pregovorima izme-

${ }^{26}$ AJ, 837, KPR, II-1/162, Poseta SAP Vojvodini, Razgovor predsednika Tita sa delegacijom Vojvodine.

${ }_{27}$ AJ, 837, KPR, II-1/162, Poseta SAP Vojvodini, Izlaganje predsednika Tita na sastanku... 
đu proizvođača i prerađivača nafte oko integracija. Upravo je u integracijama viđen izlaz iz ovih problema, ali su se pregovori Naftagasa i INE oko integracije otegli u nedogled, a jedan od kamena spoticanja, pored sporova oko podele tržišta, bili su i dugovi koje je INA već imala. Tito je bio izričit da Jugoslavija ne može ići „parcijalno, svako preduzeće za sebe“, pa je insistirao da se "naftaši“ udruže, a isto je očekivao i u hemijskoj industriji. Čak je političkom intervencijom, $u$ čemu je veliki udeo imao i Tito, sprečeno podizanje novih lokalnih rafinerija u Skoplju, Kopru i u Crnoj Gori, koje bi imale male kapacitete. Tito se protivio otvaranju ovih „novih republičkih prčvarnica“. Njegova argumentacija je bila sledeća: „Ja sam rekao, ako mi otvorimo granice za uvoz nafte onda ste vi mali prvi propali; uložićete ogromna sredstva, a prvi ćete propasti. A to možemo svaki dan učiniti. Prema tome, nema perspektive za njih. Ono što sad postoji to bi trebalo da se integriše i da se dalje razvija“. Ne krijući nezadovoljstvo sporošću integracionih procesa, Tito je insistirao da se pregovori oko integracije ubrzaju i postigne dogovor na jugoslovenskom nivou. ${ }^{28}$

Pokrajinsko i državno rukovodstvo je bilo zabrinuto i zbog posledica koje bi ekonomski problemi mogli da izazovu, a od kojih su neke već bile vidljive. Najviše su strahovali od socijalnih i političkih nezadovoljstava. Predsednik CK SK Vojvodine Mirko Čanadanović je ukazivao na pojavu „otvorenih i oštrih prigovora od radnih ljudi“, jer su nerešeni privredni problemi otvorili brojna socijalna pitanja: višak radne snage koja je oslobođena modernizacijom sela; veliki broj studenata i đaka (osnovno školstvo je obuhvatilo skoro $100 \%$ dece, a preko $80 \%$ omladine je produžavalo školovanje u srednjim školama), ali je ipak kao „centralno ekonomsko i političko pitanje“ postavio pitanje zaposlenosti. Ovo pitanje je "naročito oštro" isticala omladina. Izneo je podatak da je 1968. oko 30.000 ljudi u Vojvodini tražilo posao, a kao posebno zabrinjavajući podatak istakao je da oko 6.000 kvalifikovanih i visokokvalifikovanih radnika, pre svega mlađih, koji su završili škole učenika u privredi nemaju posao. Ekonomska kriza, po njegovom mišljenju, izrodila je i političke probleme: „Nama je politički sada u Vojvodini posebno teško da... govorimo da su sve teškoće prolazne, privremene itd. Pokazuje se, na žalost, da su te teškoće konstanta našeg razvitka i života evo već punih 3 godine. Formula 'prelazne teškoće', 'privremeni problemi' politički sve teže prolazi“. Takva situacija bi mogla da ugrozi i "skladan međunacionalni odnos" u Vojvodini, a to bi bila "kap koja prevršuje“. Bojao se da bi „nestrpljenje“ zbog ekonomskih problema moglo da otvori prostor za „demagogiju, pa i za neku drugu ideologiju, pre svega onu susetsku istočnu" i obavestio Tita da je u Vojvodini 1968. bilo 115 radnih organizaci-

${ }^{28}$ AJ, 837, KPR, II-1/162, Poseta SAP Vojvodini, Razgovor predsednika Tita sa delegacijom Vojvodine. 
ja sa preko 13.000 zaposlenih koji su mesecima ili godinu dana živeli od minimalnog ličnog dohotka, pa je 1967. i 1968. u pokrajini bilo 36 štrajkova. Za pokrajinsko rukovodstvo i za Tita nije bilo dileme da je integracija u mnogim slučajevima predstavljala jedini spas za posrnula preduzeća i da je opstanak malih preduzeća sa manje od 250 zaposlenih, a oni su činili polovinu industrijskih kapaciteta, bio nemoguć, ali je Čanadanović uveravao Tita i da je suočavanje sa radnicima u tim preduzećima "vrlo neugodno" i politički i etički, jer oni „uvek postavljaju prvo pitanje: koliko su oni sami krivi što su došli u takvu situaciju, a koliko su i drugi krivi što su oni u tom položaju“. ${ }^{29}$

Tito i partijsko rukovodstvo pokrajine su analizirali i situaciju u partijskom članstvu na kraju sedme decenije 20. veka. Podatak o 126.000 članova SK u pokrajini je bio impozantna brojka, ali se postavljalo pitanje kvaliteta partijskog članstva. Čanadanović je uočavao gubitak smisla za realnost kod dela članova, a da je drugi deo „sasvim neborben“ i zaključio: „Nakupilo se i među nama u Savezu komunista ljudi sa različitim ambicijama... Ne možemo pobeđivati ako imamo toliko ljudi koji ne znaju gde su, koji se politički kolebaju, neće da uđu u bitku“. Tito se složio, tražeći da u SK budu samo borci „kao što je nekad bilo“, kako bi Partija bila „čista“ i „oslobođena svakog balasta unutra". ${ }^{30}$

Tito je svaku priliku koristio da se osvrne na međunarodnu situaciju i da ocenu spoljnopolitičkog položaja Jugoslavije, a za tako nešto je imao i poseban motiv svega nešto više od pola godine posle sovjetske intervencije u Čehoslovačkoj. To je bio deo razgovora sa pokrajinskim i srpskim rukovodstvom u kome nije bilo mesta za stavove ostalih učesnika u razgovorima. Tito je bio spreman da satima sluša pokrajinske, savezne i republičke rukovodioce kako mu opisuju tešku situaciju u privredi, posebno u poljoprivredi, ali je spoljna politika bila rezervisana samo za njega. Iako je Jugoslavija otvoreno iskazala nezadovoljstvo sovjetskom intervencijom u Čehoslovačkoj, Tito je upozorio da jugoslovenske novine ne bi trebalo da i dalje „tjeraju po starom, one treba da prestanu da budu veći katolici od pape“. Situacija u Čehoslovačkoj se nije razvijala u skladu sa jugoslovenskim željama, ali je za Tita to ipak bila „njihova stvar“. Zato je podvukao: „Mi ne možemo sada zbog Čehoslovačke ratovati protiv Rusa", a kao najjači motiv za takvu politiku naveo je brojne ekonomske aranžmane jugoslovenskih firmi sa sovjetskim. Tito nije želeo da Jugoslavija napusti svoje principe, ali je hteo da spoljna politika bude takva da ne pravi Jugoslaviji mnogo ekonomskih teškoća: „Sve ono što nije od principijelne važnosti, a može da iritira (misli se na SSSR - S. S.) - moramo izbjegavati“. ${ }^{31}$

\footnotetext{
${ }^{29}$ Isto.

${ }^{30}$ Isto.

${ }^{31}$ Isto.
} 
Slobodan Selinić

THE VISIT OF THE PRESIDENT TITO TO VOJVODINA PROVINCE $18^{\text {th }}-21^{\text {st }}$ APRIL 1969

\section{Summary}

Yugoslav president Tito visited Autonomous Province of Vojvodina $18^{\text {th }}$ to $21^{\text {st }}$ April 1969. During those four days Tito visited several cities, Naftagas oil industry, held the meetings with the Province party leadership, as well as with the members of the Serbian party leadership and talk with the representatives of the agricultural establishments and organizations and common people. All of the meetings showe $d$ that the Province was in difficult economical problems, that its development was weaker from the potentials and possibilities that it had. Although an agricultural region with reach potentials, Vojvodina's development was even weaker than Yugoslav or Serbian average. Tito pleaded for the integration of oil and chemical industry at the Yugoslav level, which he supposed that may have bost for the Vojvodina potentials. 